\title{
Wither black theology of liberation? Perspectives from the late Professor Vuyani Vellem
}

\begin{tabular}{|c|c|}
\hline $\begin{array}{l}\text { Author: } \\
\text { Jerry Pillay }{ }^{1} \text { (D) }\end{array}$ & \\
\hline $\begin{array}{l}\text { Affiliation: } \\
{ }^{1} \text { Department } \\
\text { and Historical } \\
\text { Faculty of The } \\
\text { Religion, Univ } \\
\text { Pretoria, Pretc } \\
\text { South Africa }\end{array}$ & $\begin{array}{l}\text { Systematic } \\
\text { Theology, } \\
\text { ology and } \\
\text { ersity of } \\
\text { ria, }\end{array}$ \\
\hline $\begin{array}{l}\text { Research Proj } \\
\text { Project Leade } \\
\text { Project Numb }\end{array}$ & $\begin{array}{l}\text { ct Registration: } \\
\text { : J. Pillay } \\
\text { er: } 04653484\end{array}$ \\
\hline $\begin{array}{l}\text { Description: } \\
\text { This research } \\
\text { project, 'Africa } \\
\text { and Developm } \\
\text { by Prof. Dr Jer } \\
\text { Department o } \\
\text { History and Cr } \\
\text { Faculty of The } \\
\text { Religion, Univ } \\
\text { Pretoria. }\end{array}$ & $\begin{array}{l}\text { s part of the } \\
\text { n Christianity } \\
\text { ent', directed } \\
\text { y Pillay, } \\
\text { f Church } \\
\text { urch Polity, } \\
\text { ology and } \\
\text { ersity of }\end{array}$ \\
\hline $\begin{array}{l}\text { Correspondin } \\
\text { Jerry Pillay, } \\
\text { jerry.pillay@u }\end{array}$ & $\begin{array}{l}\text { guthor: } \\
\text { o.ac.za }\end{array}$ \\
\hline $\begin{array}{l}\text { Dates: } \\
\text { Received: } 03 \mathrm{~J} \\
\text { Accepted: } 13 \\
\text { Published: } 21\end{array}$ & $\begin{array}{l}\text { uly } 2020 \\
\text { Aug. } 2020 \\
\text { Dec. } 2020\end{array}$ \\
\hline $\begin{array}{l}\text { How to cite th } \\
\text { Pillay, J., } 2020 \\
\text { theology of lib } \\
\text { Perspectives } f \\
\text { Professor Vuy } \\
\text { HTS Teologies } \\
\text { Theological St } \\
\text { a6232. https:/ } \\
\text { 10.4102/hts.v }\end{array}$ & $\begin{array}{l}\text { is article: } \\
\text { 'Wither black } \\
\text { eration? } \\
\text { om the late } \\
\text { ni Vellem', } \\
\text { Studies/ } \\
\text { Idies } 76(3) \text {, } \\
\text { /doi.org/ } \\
6 i 3.6232\end{array}$ \\
\hline $\begin{array}{l}\text { Copyright: } \\
\text { (C) 2020. The A } \\
\text { Licensee: AOS } \\
\text { is licensed un } \\
\text { Creative Comr } \\
\text { Attribution Lic }\end{array}$ & $\begin{array}{l}\text { uthors. } \\
\text { S. This work } \\
\text { ler the } \\
\text { lons } \\
\text { ense. }\end{array}$ \\
\hline Read online: & \\
\hline 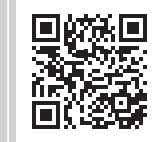 & $\begin{array}{l}\text { Scan this QR } \\
\text { code with your } \\
\text { smart phone or } \\
\text { mobile device } \\
\text { to read online. }\end{array}$ \\
\hline
\end{tabular}

The future of a black theology of liberation (BTL) has been in question since the demise of apartheid in South Africa. The constitution of democracy in the country has raised questions about the relevance and purpose of such a theology in the wake of a new dispensation. Can we continue to promote the idea of 'blackness' in a democratic South Africa? Extracting from the contributions of the late Professor Vuyani Vellem, and as a tribute to his work, this article aims to show that BTL definitely has a valid role for relevance and continuity. The author conducts a literature review of the material produced by Vuyani Vellem and identifies the emerging trends in which BTL continues to be alive and relevant.

Contribution: The scholarly contribution of this article is its focus on the systematic and practical reflection, within a paradigm in which the intersection of religious studies, social sciences and humanities generate an interdisciplinary contested discourse.

Keywords: theology; liberation; blackness; life; prophetic; Kairos; racism; empire; ecumenical; contextual; Accra Confession; apartheid.

\section{Introduction}

'Gone too soon' are the words that always dominate my mind whenever I read or reflect on the contributions made by the late Professor Vuyani Vellem (VV) to theological engagement and especially to Black Theology of Liberation (BTL). Vuyani has been a personal friend, colleague and fellow minister in the Uniting Presbyterian Church in Southern Africa. He joined the University of Pretoria in 2010 and taught and researched in the Department of Systematic and Historical Theology until his untimely death in December 2019. This article is an attempt to capture some of his valuable contributions to the development of BTL in South Africa.

Since the demise of apartheid in South Africa and the establishment of the new democracy, many have questioned the continued existence and relevance of Black Theology noting that it is essentially a theology emerging out of a particular political context addressing the oppression and dehumanisation of black people in South Africa. With the change of events and circumstances in the country, where blacks have risen in political leadership and other spheres of life, is the focus on Black Theology of liberation (BTL) still necessary?

Professor Vuyani Vellem (VV), an ardent proponent of and a scholar in BTL, has made significant contributions attempting to posit the relevance and necessity of BTL. He made the point that BTL is not in crisis but rather the whole project of Eurocentric theology in the 21st century is and he, therefore, proposed that 'un-thinking the West might be the best option in the development of life-affirming forms of theological knowledge' (2017:2). This is a very valid point as we consider the shift of Christianity to the Global South, the changing dynamics in the world, and the consistent critiques levelled at the epistemologies of the West that continue to perpetuate the tendencies of Empire. The recent outcry for justice in the murder of George Floyd demonstrated how black people continue to be viewed and treated across the globe; it saw the resurgence of the 'Black Lives Matter' movement in the United States of America.

This article aims to outline the ideas offered by VV to keep BTL alive and relevant. The author recognises that VV is not the only one to address the question of BTL relevance in South Africa. There is, admittedly, a wide body of literature that does the same (e.g. Boesak 1978, 1984; Maluleke 1995; Moore 1973; Mosala 1989; Motlhabi 2009; Tshaka \& Makofane 2010). Because this research is an appreciation and acknowledgement of the work that late VV had contributed to the topic in discussion, the author will focus mainly on his insights towards the relevance of BTL today. I shall

Note: Special Collection entitled VukaniBantuTsohangBatho - Spirituality of Black Liberation, sub-edited by Fundiswa Kobo (UNISA) and Rothney Tshaka (UNISA). 
now proceed to illustrate this by reflecting on some of the trends impacting on the understanding and appreciation of Black Theology as presented by VV.

\section{Black theology as a theology of liberation}

Vuyani Vellem often mentioned that he was not opposed to any renditions of the name Black Theology of Liberation or Black Liberation Theology but he would have a problem if the word 'Liberation' was omitted (Laubscher 2018:2). He seemed to distinguish between 'a Black theologian' and 'a Black theology of liberation'. This is a significant distinction. In the context of liberation, 'Blackness' is not understood:

$[A]$ s a biological or anthropological construct without necessarily denying ontological Blackness, but an existential term. BTL is not a pigmentocratic discourse, but a state of mind, a consciousness and an existential project of Blackness. (p. 4)

Vuyani Vellem compared this with the system of 'Whiteness', which he claimed is responsible for the creation of 'Blackness'.

Liberation theologians point out that liberation is a continued task because oppression, poverty, unjust economic systems, racism and social injustices will always be with us in the world. Therefore, the need to be liberated from something, whatever it may be, would never be exhausted. Tshaka (2010) affirmed this view and lamented the fact that BTL did not adequately define the notion of freedom hence the confusion about the role of BTL today.

In South Africa, apartheid may be dismantled but it does not mean that racism is gone. In fact, over the past 20 years since its democracy, South Africa has seen the resurgence of racism in many quarters and some people have been charged for their public racial utterances.

Vuyani Vellem has argued that racism per se is not the issue but White supremacy or superiority is problematic. However, racism, he admits, is impossible without superiority. For VV the structures and systems continue to dehumanise black people. These are systems that are products of colonisation and conquest, systems of superiority marking black bodies as dispensable. Dismantling apartheid does not necessarily mean that black people are set free; this cannot be the case when systems continue to favour certain people, when economic systems continue to enable the rich to get richer and the poor to become poorer, when redistribution of wealth has not favoured the poor and social conditions have not changed. This, according to $\mathrm{VV}$, is the result of racist and colonial systems still being in place. He believed that we should fight for the rights of black people, and this meant resisting systems that sustained white privileges and positions, something he did with passion and intolerance. Vuyani's obsession with 'blackness' often earned him the criticism of being anti-white and of projecting racism in reverse. However, he was not understood. His focus on blackness was not on pigmentation but on the state of mind, a consciousness and an existential project of blackness.
This discussion can, perhaps, be seen more clearly in VV's resistance to systemic racism, which he strongly vocalised in the context of the church. He argued that:

The church must be unshackled from the colonial legacy and its pervasive trauma that remains a ferocious residue in South Africa post-1994. It must be unshackled from the pigmentocratic structures that have gone more than 21 years into our democracy ... The church must be unshackled from being an instrument of cultural domination by those who perpetuate the hegemony of ecclesiological insights and theologies that present their cultures as normative in the interpretation of the gospel of Jesus including those who grudgingly accept that the heartland of Christianity is now in Africa. The church must be unshackled from its complacency with a life-killing capitalist exploitation, with its attendant cultural and psychological maladies that continue to assimilate, co-opt and destroy the cultural and psychological resources on which the previously oppressed have continued to survive. (Vellem 2015:5)

The addition of 'liberation' to black theology changes the nature, longevity and discourse of understanding black theology. Vuyani Vellem was inspired by James Cone's work in this regard and his coinage of the term 'A Black Theology of liberation'. Black Theology is thus perceived as a theology of liberation. A theology that asserts 'blackness' not in the sense of skin colour but in 'the terms and grammar of BTL [which] is opened up by spaces and experiences of Blackness, [woundedness] or the wretched of this world' (Laubscher 2018:4). In this sense, such a theology would continue to assert its relevance and praxis, not only in South Africa but worldwide.

\section{A prophetic theology}

Vuyani asserted the prophetic dimension of BTL, and it is not surprising that he often spoke prophetically denouncing systems that militated against the assertion of 'blackness'. He, however, bemoaned the fact that post-1994 more emphasis has been rather on the notion of prophetic theology whose relationship with the liberation paradigm [were] becoming equally unclear' (Vellem 2012:n.p.). In an article in SHE (Vellem 2012:n.p.) he traced the debates and 'differences between prophetic theology and BTL [firmly locating] the interlocution of BTL with the voiceless in the 21st century'. With this in mind VV explained the prophetic motif ${ }^{1}$ in BTL:

One of the descriptions of Black Theology I offer is that it is a cogent response to the internal contradictions of Christian theologies that baptise allegiance to the status quo within the external sociopolitical challenges experienced as painful, violent exclusion and domination by the Black African masses in the country of their birth. The Black Theology of liberation entails that much of science, philosophy and religion are ideological constructions intent on protecting the interests of the powerful against the oppressed. In this manner, the Black Theology of liberation challenges forms of power, such as racism, patriarchy, sexism and economic exclusion, which perpetuate the oppression of the poor ... Therefore, as a liberation theology, the goal of Black Theology is to open the horizons of those who suffer vicious oppression and domination in their land of birth. (Vellem 2010a:4)

1.Vuyani referred to the various streams that can be seen in BTL: (1) resistance of black Africans against colonialism referred to as the 'Protest Model', (2) the 'Confessing Model' and (3) the 'Contextual Model' (Vellem 2010:4-5). 
Theology is a contextual theology. According to Van der Water (2015 in Vellem 2010:n.p.), 'contextual theologies are virtually no different from Prophetic Theology and their integration is necessary for the development of Prophetic Theology in South Africa'. Black theology of liberation is, indeed, a prophetic theology as it speaks against injustices, evil and suffering in the world. It is a theology that takes seriously the 'preferential option of the poor'.

In order to illustrate the prophetic nature of BTL, Vuyani tended to link it to certain confessional statements that reflect a prophetic message and tone. In this regard, he showed a great appreciation for the Kairos Document that emerged in South Africa in 1983. Vuyani Vellem argued for a link of the Kairos Document to BTL emphasising that Kairos Theology is a direct product of BTL and he expressed hesitation with those who attempted to delink this connection, accusing them of 'innovative haste' (Vellem 2010:2).

\section{Vellem (2010):}

Kairos theology is prophetic in its interpretation of the Gospel. The convergence of contextual theologies and Kairos theology occurs at the point of the experience of crisis by ordinary people and is indicative of how they attempt to reflect on their faith in such crises. The poor constitute their normative context, in which prophetic theology begins, as a conversation with God. (n.p.)

The Kairos Document is a Christian, biblical and theological commentary on the political crisis in South Africa that took seriously the experiences of black people. It spoke of the crisis in the church, which was born out of the divisions in the church. Consequently three trends developed from these divisions, that is, state, church and prophetic theology. The document challenged the state on its ideologies and condemned apartheid as a heresy. More particularly it challenged church theology in three interrelated ways: (1) the lack of proper social analysis, (2) lack of understanding of politics and political strategy, and (3) the type of faith and spirituality that was dominant in the church (see Pillay 2002:122). The document stated that apartheid by its very nature is both divisive and antithetical of a just social order and reconciliation.

Similarly, VV viewed the Belhar Confession (BC) as a product of BTL. He affirms that the formulation of this Confession must be seen against the background of its emergence. The $\mathrm{BC}$ is a product of the rupture that took place since the Sharpeville massacre, which also raised the question of blackness and its relationship with Christian faith. The Confession is not only a critique but a call to an embodiment of an alternative, life-affirming Christianity. It is a call 'to stand where God stands, namely against injustice and with the wronged', the courage to know that 'in following Christ the church must witness against the powerful and privileged who selfishly seek their own interests ...' It is the courage with which the BC closes:

We believe that in obedience to Jesus Christ ... the church is called to do all these things, even though authorities and human laws might forbid them and punishment and suffering be the consequence. (p. 3)
The Confession invokes the prophetic calling of the church and in this sense the BTL can identify fully with it.

Vuyani was also an ardent propagator of the Accra Confession (AC), adopted by the World Alliance of Reformed Churches in 2004, stating that it is a sound example of how a prophetic voice can be blown in the era of 'regime change', which continues to widen the gap between the poor and the rich (Vellem 2010:6).

Though not a doctrinal confession like the Heidelberg Catechism or Westminster Confession, the Accra Confession challenges current economic doctrines with the traditional Reformed criticism of idols (i.e. Mammon, consumerism, the financial and speculative markets) that deny God's lifegiving sovereignty and defy God's covenant by excluding the poor, the vulnerable, and the whole of Creation from the fullness of life. In essence the Accra Confession is a response and resistance to Empire (Pillay 2018). The Confession defines empire as (Pillay 2018):

$[T]$ he convergence of economic, political, cultural, geographic, and military imperial interests, systems, and networks for the purpose of amassing political power and economic wealth. Empire typically forces and facilitates the flow of wealth and power from vulnerable persons, communities, and countries to the more powerful. The Bible is full of stories of empire rising, over-extending, and falling. Empire today crosses all boundaries, strips and reconstructs identities, subverts culture, subordinates nation states, and marginalizes or co-opts religious communities. (p. 3)

In the body of the text, the Confession does a reading of the signs of the times. It points out that 'we live in a scandalous world that denies God's call to life for all' (AC point 7). It refers to the debt of poor countries, the drive for profit of transnational corporations, climate change, crisis caused by the development of neoliberal economic globalisation and an ideology that claims to be without alternative (AC point 9). The Confession attributes these challenges to empire' (in Pillay 2018):

We recognise the enormity and complexity of the situation. We do not seek simple answers. As seekers of truth and justice and looking through the eyes of powerless and suffering people, we see that the current world (dis)order is rooted in an extremely complex and immoral economic system defended by empire. (AC point 10)

The Confession then moves to a section titled 'Confession of faith in the face of economic injustice \& ecological destruction'. In this section, from paragraphs 14 to 36 , it offers a theological response to empire. It states that:

$[W]$ e believe that the integrity of our faith is at stake if we remain silent or refuse to act in the face of the current system of neoliberal economic globalization and therefore we confess before God and one another. (p. 3)

Pillay (2018) states that:

The Confession then proceeds to clearly set out what it believes and in light of that, what it rejects. The 'reject' aspects are, in my 
opinion, strong resistance to empire from a theological and biblical perspective. (n.p.)

Vuyani was deeply caught up with the idea of Empire and believed that BTL is a theology of resistance - resisting Empire. This can be clearly seen in his article Black Theology of Liberation: A theology of life in the context of Empire (Vellem 2015). In a further article, Vuyani emphasises the Christian resistance to Empire by connecting the resurrection of Jesus to insurrection (Vellem et al. 2016:153-162). Here he draws from Allan Boesak who affirms, 'For those who follow him, the resurrection is Jesus' ... rebellion (Boesak 2015:30). The idea of rebellion and resistance is the key to understanding the prophetic nature of BTL.

Vuyani considered the 'Protest' and 'Confessing' Models in the streams of BTL to provide a creative link between the prophetic theology in the Kairos document, the ecumenical confessions and the BTL. In his view, these approaches did not 'only expand the contours of traditional theology, but also understood confession as a political praxis', taking seriously the interest of the poor and providing 'an alternative community based on the principles of the reign of God' (Vellem 2010:1).

\section{A theology of life and hope}

Vuyani was deeply influenced by the statement produced by the Ecumenical Association of Third World Theologians in 1993 titled: A Cry for Life: The Spirituality of the Third World, which was published in the Journal of Black Theology in South Africa. The sentiments of this statement are expressed in the following:

The cry of the Third World is not a passive cry of resignation to the realities of death. It is a strident witness to the persistence of life. The cry for life is not a cry of despair, sorrow, hopelessness or grief. It is a cry that denies victory to torture, detainment, starvation and military might. It is a cry for bread, rice, water, land, housing, jobs health care. (p. 47)

Drawing from this, Vuyani framed his thoughts about BTL as a theology of life and hope - a theology that took seriously the plight of the poor, oppressed and dehumanised. A theology that struggles against Empire, which is life-denying. It is a theology that embraces the:

$[R]$ esistance of the young people and their anger, women and their struggles against patriarchy, including all these currents that inspire a new vision of living, express hope that denies death and affirms life. The development of distinctive theologies by women in addition to class and race constructs that deny black peoples their dignity and life, is an expression of the power of the oppressed to say 'no' to death. (Vellem 2015:2)

In this sense, VV understood BT in South Africa as a theology of human dignity but expressed the difficulty of defining the term in a systematic way and set out to challenge certain contemporary understandings of human dignity (Vellem 2010:314-321). It is important to note that black theology in South Africa was born in the context of the South African liberation struggle; it is synonymous with the apartheid struggle. It was a black consciousness movement that affirmed the dignity of the majority of South Africans and their history and also helped them to rediscover their identity (Van Aarde 2016:1). For Mbiti, black theology stands in a continuity with Latin American liberation theology, which is a theology of conflict on behalf of the poor and the marginalised (Mbiti 1974:41-44). It does not simply act on behalf of the poor and the marginalised but draws them into the struggle on the grounds of human dignity and black identity.

Black theology of liberation is a theology that affirms life. Let us allow Vuyani to explain BTL as a theology of life:

Black Theology of liberation, by locating itself in zones of the will to live by the life-lessened oppressed, is a theology of life ... If for one moment, apartheid in South Africa is perceived as the zenith of the Western justificatory logic of racial violence and oppression and the imperialist phase of 'primitive accumulation' that dispossessed the material and spiritual resources of black Africans through colonialism and Christianization, then the task of Black Theology of liberation as a discourse of life should be easy to grasp ... locating itself within the experiences of suffering and the struggle history of the racially subjugated, Black Theology of liberation, like Dalit, Minjung, Womanist and Latin American brands of liberation, is quintessentially a theology of life. (Vellem 2015:3)

It is in such a context that VV understood BTL to be a lifeaffirming theology. He explains this further by linking the BTL in North America as having an intrinsic relationship with Black Power and in South Africa with Black Consciousness. Vuyani Vellem captures this well:

The relationship between Black Theology of liberation and Black Power is thus a relationship between Black Theology of liberation and 'lifeless black life' we need to note this paradox. In the same manner Black Consciousness in South Africa is a concept that speaks to the lifeless life of blacks in so far as their death of consciousness implies the total absence of life in their condition of embodied or bodily oppression. Understood in this way therefore, the relationship between Black Theology of liberation and Black Power and Black Consciousness places Black Theology as life-giving. Stated otherwise, the reality and experience of powerlessness or death of consciousness in the harsh and crushing conditions of the lived-space of the black persons is the reality of death, living death, while the affirmation of the power and consciousness of black people is the affirmation of life ... It should be clear that the overall vision - the archaeology of the liberation paradigm in theology is thus the affirmation of life and again not just any life, but the lives of those who are literally and virtually lifeless. This is one of the distinguishing features of this paradigm, the affirmation of disconfirmed, lifeless lives as a starting point of doing theology. Inevitably, the orientation of Black Theology of liberation and other theologies of liberation to life is their irruption in crises - crises of life. (p. 3)

Vuyani Vellem pointed out that 'unmasking the universe of Empire is the task of a BTL as a theology of life' (Vellem 2015:1). In reflecting on the notion of human dignity he highlighted:

[T]he inherent historical tension and even contradictions regarding the concept, especially when viewed in the light of the 
experience of black Africans and the experience of colonization and oppression. (Vellem 2010:3)

Reflecting on the metaphors of the Serithi/isidima, he challenged certain contemporary understandings of human dignity (see Vellem 2010: 314-321) and firmly connected it to the sufferings of the poor.

Vuyani agreed with Boesak (1984:62; Van Aarde 2016) that the:

[F]ocus was not primarily about liberation from oppressive structures, [as in the case of Liberation Theology], but a rediscovery of human dignity and identity. Freedom without dignity and identity is no freedom at all; in fact, it is another form of bondage. (p. 4)

Boesak sees black theology as positive: 'It speaks of Christian hope where so many have lost all hope' (Boesak 1984). However, Boesak explains that this 'hope is not a romanticised piousness, which denudes Hope of her radical presence in people's lives, thereby shielding ourselves from Hope's radical demands' (Boesak 2014:46). Instead it is a hope that expresses anger and courage; anger as it shares in God's outrage at injustice and courage to share God's love for justice. It is a hope that 'confronts the imbalances of power and abusive power structures, but it does so in order to restore human dignity and identity, which is true freedom' (Van Aarde 2016:4). This is precisely how Vuyani understood BTL and its struggle for justice, freedom, human dignity and life. Black theology of liberation is a call to stand where God stands with the poor and oppressed in their life-denying experiences holding out hope and affirming life, in this we see its continued relevance and standing.

\section{A diakonial theology}

For Vuyani, BTL is a theology that advocates praxis. To enable justice to flow, it is imperative to act against and resist the forces of Empire that continue to perpetuate colonial and racist tendencies. In this sense BTL is an action theology of resistance, change and transformation. It does not merely talk; it does, meaning that it actively works for the creation of a new community and world in line with the reign of God.

In this regard, I would like to propose that BTL is a diakonial theology and consequently continue to assert its relevance today. ${ }^{2}$ Church of Jesus Christ has normally understood diakonia to be an essential part of its mission task. This is normally evidenced in its care and concern for the poor and needy. However, over the ages this understanding of diakonia has come to the realisation that the root causes and effects of poverty, inequality and injustice must also be addressed in changing the material conditions of the poor and needy. Thus, over the years, the concept of diakonia has broadened to include involvement in the life of humankind, in making of nationhood, building of culture, structuring of society with its functions and institutions and in shaping the form and quality of political systems to work towards justice. Diakonia is also linked to the idea of development and globalisation (Pillay 2002). The Lutheran World Foundation broadened the term diakonia to capture the aspects of human rights, social justice and empowering individuals, by using the term 'transformational diakonia' affirming that:

Transformation engages and changes all who are part of it. In that manner, transformational diakonia helps to overcome so-called helpers' syndromes, practices and relations that separate 'we' from 'they'. In the end, no person escapes vulnerability. We all need to be transformed, reconciled and empowered ... Transformation is clearly a process, but at the same time, transformation envisions the achievement of certain goals, arriving at a new situation where human dignity is more respected with peace and justice for more people. Thus, transformation is closely related to what also may be defined as social change, progress or development. (Nordstokke 2009:43-44)

Black theology of liberation is about the development and transformation of society; about protecting, defending and establishing social justice, human rights, human dignity and the sanctity of life. In this sense it is a theology of praxis and diakonia, which would continue to have relevance and significance in the world today.

\section{An ecumenical ${ }^{3}$ theology}

Vuyani joined the South African Council of Churches (SACC) in 2008 as Deputy General Secretary. He understood the BTL as a comprehensive project for the liberation of the poor and saw in the SACC a natural home for BTL. In his view, the founding of the SACC in 1968 was coterminous with the emergence of BTL since the SACC was prompted by the Sharpeville massacre and the Cottesloe Consultation in 1961. John De Gruchy (2005:133) pointed out that by 1972, the SACC had a majority of blacks in its executive, thus producing 'structural indigenisation' and autonomy.

In the mind of VV ecumenism was a form of socio-political praxis. The SACC and other ecumenical movements seem to espouse a 'new way of doing theology in the light of the suffering and oppression of black people' which seemed attractive to BTL proponents (Vellem, in Conradie 2013:180). Graham Duncan whilst referring to ecumenism in South Africa points out that ecumenism is shaped by many movements and factors. He then proceeds to talk about ecumenical struggle rather than ecumenical movements (2019:1-16).

In a similar way, VV expressed his concern and sense of dissatisfaction with the direction ecumenical movements were taking, in his view a diversion from what it should be doing. He raised the question of who black Africans are and whether they are bound in the ecumenical world (Vellem 2013b, in Conradie 2013:183). His contestation was that the struggle for justice of black Africans were not taken seriously.

3.Diakonia could be linked with being ecumenical. For example, the wcC talks about 'ecumenical diakonia'. I speak about ecumenical theology under a separate heading to emphasise the strong ecumenical element in BTL. 
For example, referring to the crisis Liberation Theology caused in the World Council of Churches (WCC), VV applied the same to the ecumenical discourse in South Africa. He pointed out that Liberation Theology has posed challenges to ecumenism and this has generally resulted because of the tension of orthodox ecumenical imaginary and the ecumenical vision of liberation.

Whilst recognising the importance of Christian unity, Kasper (2005:3) cautioned:

$[U] \mathrm{s}$ to bear in mind the changing ecumenical scene of the 21st century. [He emphasises practical ecumenism and] perceives the unity of the Church not as a goal in itself. Rather he understands the unity of the Church as an instrument, sign and anticipation of the unity of all humankind. According to Kasper, the universal context of the commitment for the unity of the Church has further implications for social and political diakonia, practical witness, and for the dignity of the human person and for human rights, for the sanctity of life, family values, education, justice and peace, healthcare, the preservation of creation and last but not least interreligious dialogue. (pp. 3-5)

It is interesting to note that Dr Olav Tviet, the outgoing General Secretary of the WCC, had this to say in his final sermon on 31st March 2020, which captures the expressed sentiments:

When the WCC was established, they came out of a catastrophe caused by some who wanted to be the ruler, the lord of that time. It led to a world war, to genocide, and to enormous suffering and disasters. They who got together in 1948 formulated that the basis of the WCC is our faith in Jesus Christ 'as Lord and Saviour' ... The WCC is born in crises, and established to continue to address crises; out of distance and division among the churches, out of the disasters of the World Wars of the 20th Century, to end colonialism and to combat racism, to work for the end of the cold war and the threat of nuclear annihilation, to prevent and end armed conflicts, to stop the abuse and destruction of God's creation, to address climate changes, to combat globalization when it makes a few rich and the many poor, to fight poverty, to stop violence in the name of religion, to advocate for the rights of refugees, to oppose destructive nationalism that divides and kills, to address illness and endemics, stigmatization and exclusion of HIV, to end gender based violence, to end violence against children and so forth. This is our time-just now it is also the time to address the crisis we are facing. There is a constant need for an ecumenical movement that is a movement of love and care.

Although VV did not describe BTL as an ecumenical theology as such; there is no doubt that he believed in the work of ecumenical movements to further the ends of justice and peace in a world filled with greed and imbalanced power crying out for economic, gender and ecological justice. In this, he undoubtedly saw a home for BTL. Therefore, it is not surprising that VV offered himself to ecumenical engagements and organisations asserting that the struggle for (black) liberation should shape ecumenical witness. His understanding of ecumenism is what prompted his involvement.

\section{Smit (2003) states that:}

Ecumenism is concerned with the world. This has always been the case in history, whether in earlier centuries, or during the self-consciously ecumenical twentieth-century. The Greek word oikoumene refers to the whole inhabited earth [see Conradie 2013:14-15] ... From the perspective of Christian faith, the Ecumenical Movement sees the world in a particular light - of what it is, could be, should be, and will become. In recent years, attempts have increasingly been made to use the metaphor of oikos, household, implied in the oikoumene, to develop this vision further. Ecumenical leaders and theologians are deliberately relating the oikoumene of the church to the oikounomia or fullness of the life of the Trinitarian God, to be reflected in the life of the church. The oikoumene is furthermore related to the global political and economic realities. (p. 424)

In recent times we are now speaking of transformative ecumenism, which is a call to root ecumenism (Plaatjies Van Huffel 2017):

[I]n the people's struggle for justice and life, an ecumenism that envisions not only the unity of the church like in conciliar ecumenism (Bujo 1992). Rather, Transformative ecumenism focuses on the unity of whole humanity and creation. (p. 9)

The late Mary-Anne Van Huffel in her article, 'From conciliar ecumenism to transformative receptive ecumenism' (2017), attempts to show the transitional phases of ecumenism. She does this as she gives attention to conciliar ecumenism, receptive ecumenism, transformative ecumenism ${ }^{4}$ and its implications for the development of an African transformative receptive ecumenism (Plaatjies Van Huffel 2017):

Transformative Ecumenism seeks to intentionally build a strong orientation towards justice and peace while strengthening solidarity with the marginalised groups and the grassroots communities .... [On] the [African continent this would include] a broad [range] of issues: poverty, racism, tribalism, culturalism, modernism, sexism, human trafficking, health, education, gender-based violence, climate change, economic injustice, corruption, religious conflicts, homophobia, xenophobia, etc. (p. 10)

Vuyani would have argued that transformative ecumenism is also included in BTL because blackness is more than pigmentation but a state of mind, a consciousness and an existential project of Blackness. In so far as ecumenical theology is concerned with the poor, oppressed and exploited, it is aligned to the objectives of BTL in the struggle for justice and peace. Vuyani contributed extensively to issues of justice in the theological formation of some of the ecumenical organisations, especially in the work of the Council for World Mission and the World Communion of Reformed Churches. Although Vellem (2013a) was somewhat critical of reformed tradition, he believed that to be reformed is to be ecumenical, and he, therefore, argued for reformed tradition as public theology. Ecumenical theology, in my opinion, is another nest in which BTL continues to exist with relevance and hope.

4.Transformative ecumenism was spelt out in the Concept paper of the Manilla colloquim (2016) as constituting seven elements, to live out the transformative ecumenism is to: (1) respond to the call from the margins to seek justice, (2) live inclusively in solidarity with each other, (3) actively seek first the kingdom of God, (4) empower mutually, (5) live out the subversive nature of the Gospel, (6) rooted in the dynamic spirituality of life and (7) live and love, struggle and celebrate always the dynamic spirituality of life and (7)
hopeful in God's power to transform. 


\section{Unconcluding thoughts}

The untimely death of VV is rather unfortunate, especially for the further articulation, expression and continued relevance of BTL. However, his death would not see the demise of BTL for there are many young theology students arising in theological institutions and churches in South Africa and around the globe to carry the baton to keep it alive but more significantly, as I have argued in this article, BTL continues to exist as a theology of liberation, a prophetic theology, a theology of life and hope, a diakonial theology and an ecumenical theology. Black theology of liberation is here to stay as long as there is racism, injustices and systemic evil in the world.

\section{Acknowledgements Competing interests}

The author declares that he has no financial or personal relationship(s), which may have inappropriately influenced him in writing this article.

\section{Authors' contributions}

I declare that I am the sole author of this research article.

\section{Ethical consideration}

The author confirms that ethical clearance was not needed for the study.

\section{Funding information}

This research received no specific grant from any funding agency in the public, commercial, or not-for-profit sectors.

\section{Disclaimer}

The views and opinions expressed in this article are those of the author and do not necessarily reflect the official policy or position of any affiliated agency of the author.

\section{References}

'The South African Kairos Document', 1985, viewed 20 June 2020, from en.wikipedia. org/wiki/Kairos_Document.

Accra Confession, 2005, 'That all may have life in fullness: World alliance of reformed churches', 24th General Council Proceedings, World Alliance of Reformed Churches, Geneva, pp. 153-160, viewed n.d., from https://www.ucc.org/justice/ issues/pdfs/A-Faithful-Response-Calling-fora-More-Just-Humane-Direction-forEconomic-Globalization.pdf

Boesak, A., 1978, Black theology Black Power, Mowbrays, London.

Boesak, A., 1984, Black and reformed: Apartheid, liberation and the Calvinist tradition, Skotaville Publishers, Johannesburg.

Boesak, A.A., 2014, Dare we speak of Hope? Searching for a language of life in faith and politics, William B. Eerdmans Publishing Company, Grand Rapids, MI.

5.I have chosen to use this expression as it was commonly used by Vuyani Vellem in his academic articles.
Boesak, A.A., 2015, Kairos, crisis, and global apartheid, Palgrave Macmillian, New York, NY. https://doi.org/10.1057/9781137495310

Bujo, B., 1992, African theology in its social context, transl. J. O'Donohue, Concept paper of the Seoul International Theological Colloquium for Transformative Ecumenism 2013, Orbis, Maryknoll, NY, viewed 23 June 2020, from https://www. miraeforum.org/category/Colloquium.

Conradie, E.M., 2013, South African perspectives on notions and forms of ecumenicity, SUN Press, Stellenbosch.

De Gruchy, J., 2005, The struggle of the church in South Africa, Fortress Press, Minneapolis, MN.

Duncan, G.A. \& Egan, A., 2019, 'The ecumenical struggle in South Africa: The role of ecumenical movements and liberation organisations from 1966'. Studia Historiae Ecclesiasticae 45(1), 1-16. https://doi.org/10.25159/2412-4265/3936

Kasper, W., 2005, 'The ecumenical movement', Presentation at the event marking the 40th anniversary of the Joint Working Group (JWG), between the Roman Catholic Church and the WCC, 18 November 2005, WCC Publications, Geneva.

Laubscher, M., 2018, 'Interview with Professor Vuyani Vellem', Acta Theologica 38(1), 7-14. https://doi.org/10.18820/23099089/actat.v38i1:1UV/UFS

Maluleke, T.S., 1995, 'Black theology lives! On a permanent crisis', Journal of Black Theology in South Africa 9(1), 1-30.

Mbiti, J.S., 1974, 'An African views American black theology', Worldview 17, 41-44. https://doi.org/10.1017/S0084255900025328

Moore, B., 1973, Black theology: The South African voice, C. Hurst \& Company, London.

Mosala, I.J., 1989, Biblical hermeneutics and black theology in South Africa, Eerdmans Publishing Co., Grand Rapids, MI.

Motlhabi, M., 2009, 'Phases of black theology in South Africa: A historical review', Religion \& Theology 16(3-4), 162-180. https://doi.org/10.1163/10230800 9X12561890523555

Nordstokke, K. (ed.), 2009, Diakonia in context: Transformation, reconciliation, empowerment: An LWF contribution to the understanding and practice of diakonia, Lutheran World Federation, Geneva.

Pillay, J., 2002, 'The church and development in the new South Africa: Towards a theology of development', Unpublished doctoral thesis, University of Cape Town.

Pillay, J., 2018, 'The Accra Confession as a response to empire', Hervormde Teologiese Studies 74(4), 1-7. https://doc.org/10.4102/hts.V7414.5284

Plaatjies van Huffel, M.A., 2017, 'From conciliar ecumenism to transformative receptive ecumenism', HTS Teologiese Studies/Theological Studies 73(3), a4353. https://doi.org/10.4102/hts.v7 3i3.4353

Smit, D.J., 2003, 'Living unity? On the ecumenical movement and globalisation', Scriptura 84(10), 423-437. https://doi.org/10.7833/84-0-872

The Confession of Belhar, World Alliance of Reformed Churches, Semper Reformanda viewed 20 June 2020, from http://wcrc.ch/belhar-confession.

The cry for life - The spirituality of the third world (statement), 1993, Journal of Black Theology in South Africa 1, 45-71.

Tshaka, R.S. \& Makofane, M.K., 2010, 'The continued relevance of black theology for democratic South Africa today', Scriptura: Journal for Contextual Hermeneutics in Southern Africa 105(1), 532-546. https://doi.org/10.7833/105-0-155

Van Aarde, T., 2016, 'Black theology in South Africa - A theology of human dignity and black identity', HTS Teologiese Studies/Theological Studies 72(1), a3176. https:// doi.org/10.4102/hts.v72i1.3176

Van der Water, D., 2015, 'Social struggle and faith-based activism in "Black Empowerment" times: An agenda for postcolonial mission - Sounding the horn on some African perspectives', Missionalia 43(1), 7-22. https://doi. org/10.7832/43-1-79

Vellem, V., 2010a, 'Prophetic theology in black theology, with special reference to the Kairos document', Hervormde Teologiese Studies 66(1), 1-6. https://doi. org/10.4102/hts.v66i1.800

Vellem, V., 2010b, 'Serithi/isidima: Reflections on human dignity in South Africa from a black African perspective', Scriptura: International Journal of Bible, Religion and Theology in Southern Africa 104(1), 314-321. https://doi.org/10.7833/104-0-173

Vellem, V., 2012, 'Interlocution and Black Theology of Liberation in the 21st century: A reflection', Studia Historiae Ecclesiasticae 38(Suppl. 1), 1-7.

Vellem, V., 2013a, 'The reformed tradition as public theology', Hervormde Teologiese Studies 69(1), 1-6. https://doi.org/10.4102/hts.v69i1.1371

Vellem, V., 2013b, 'Ecumenicity and a Black Theology of Liberation', in E.M. Conradie (ed.), South African perspectives on notions and forms of ecumenicity, pp. 173f, SUN Press, Stellenbosch.

Vellem, V., 2015, 'Black Theology of Liberation: A theology of life in the context of empire', Verbum Eccles 36(3), 1-6. https://doi.org/10.4102/VE.V3613.1470

Vellem, V., 2016, 'Iziko: Insurrection and resurrection', in V. Vellem, P. SheerattanBisnauth \& P.V. Peacock (eds.), Bible and theology from the underside of empire, pp. 1-7, SUN Press, Stellenbosch.

Vellem, V., 2017, 'Un-thinking the West: The spirit of doing Black Theology of Liberation in decolonial times', Hervormde Teologiese Studies 73(3), 1-6. https:// doi.org/10.4102/hts.v73i3.4737 